It is worthy of note that the original works of Gossage and others were put on waste ground at Widnes, so that the escaping acid fumes did least harm under the prevailing wind conditions to the neighbours.

Time has already largely proved that Norman was right. His early work was concerned with the recovery of copper and precious metals from burnt ore, and he devised a process for the production of a red oxide of iron pigment from the spent liquors, which was worked successfully for many years by the Liverpool and Hull Red Oxide Company.

Norman's interest in metals continued throughout his life, and he was in close contact with leading men at home and abroad on developments in the metallurgy of iron, copper, zinc, etc. In copper recovery he early recognised the merits of the Ramen mechanical furnace, and continually studied other aspects of copper recovery until post-War developments at home and abroad reduced to small dimension in England what had been a large and profitable business.

It was at Wigg Works that the Raschen process for cyanide manufacture was successfully operated for some years from 1898 on until, like other processes of the period, it had to yield place to the Castner method of starting from metallic sodium. The Raschen process was based on the oxidation of sodium sulphocyanide by air, using nitric acid as an intermediary in the oxidising vessels and regenerating this in towers from the liberated nitric oxide. Such production of nitric acid from nitrogen oxides is now carried out on an immense scale in the present-day methods of nitric acid manufacture. Prior to 1900 it was difficult, more especially in construction and design of plant and choice of material. It may be recalled that an accident on the Wigg plant demonstrated the violently explosive character of the endothermic nitric oxide-a property then barely known, but one which had to be guarded against.

In 1928, Sir Frederick gave up his position as manager of the United Alkali Company, after fiftyseven years' service, to become consultant on nonferrous metals for Imperial Chemical Industries, Ltd. He was knighted in 1914 and for his services during the Great War made a deputy lieutenant of Cheshire.

\section{Prof. F. B. Jevons}

WE regret to record the death of Prof. F. B. Jevons, formerly professor of philosophy and a vicechancellor of the University of Durham, which took place on February 29 at the age of seventy-seven years.

Frank Byron Jevons, second son of John William Jevons of Doncaster, was born on September 9, 1858. He was a scholar of Wadham College, Oxford, taking first class honours in Classical Moderations and in Literæ Humaniores. In 1882 he was appointed to the staff of the University of Durham, where he spent the whole of his academic career, being classical tutor in 1882-1910 and professor of philosophy in 1910-30. He held a number of high offices in the University, and was vice-chancellor in $1910-11$.

In his early work as a classical scholar, Jevons already showed, notably in "The Prehistoric Antiquities of the Aryan People", in his edition of Plutarch's "Roman Questions" and in his "Manual of Greek Antiquities", that his bent lay not so much in the direction of pure scholarship as in the study of the development of the religious and philosophical conceptions of the peoples of antiquity. A "History of Religion", which had already reached its seventh edition in 1896, traced the origin of religion to totemism, and established Jevons, in company with such men as Robertson Smith and Andrew Lang, as one of the protagonists in the discussions on the origin and development of religious ideas, which were a marked feature of anthropological thought at that time. His "Idea of God in Early Religion" appeared in 1910, and he was also the author, among other works, of "Religion in Evolution" and "A Study of Comparative Religion". Although recently, the diversion of anthropological studies to other methods of approach has somewhat obscured his contribution to humanistic studies, his work is of enduring value, his profound knowledge of the conceptions of antiquity compensating in some degree for his lack of first-hand knowledge of the ideas of primitive people-a lack which, indeed, he shared with the more prominent of the controversialists who were his contemporaries.

BoHemian palæontology has suffered a great loss by the death of Prof. C. Klouček on October 11, 1935. He was born in 1855 and began life as a sculptor. In 1903, when more than fifty years of age, he started collecting fossils from nodules and stones on the land in the neighbourhoods of Rokycany and Prague. In these (Lower Ordovician $D \gamma$ ) he found many new species of trilobites and other forms of life. He likewise proved that the Osek-Kván series of Ordovician age represented two distinct faunistic horizons. But his greatest discovery came from his study of the Tremadocian, which he began in 1913. Before his day, these beds were little known, so that he can be regarded as the discoverer of the Tremadocian in Czechoslovakia. He did very important work in the stratigraphy of these beds, dividing them into various horizons, according to the type fossils.

\section{WE regret to announce the following deaths:}

Prof. Robert Barany, of the University of Uppsala, who was awarded the Nobel Prize in medicine in 1914 for his work on the physiology and pathology of the ear, on April 8, aged fifty-nine years.

Major W. H. D. Clark, O.B.E., sometime chief examiner and later Assistant Comptroller of the Patent Office, on April 9, aged seventy-six years.

The Hon. Stephen Coleridge, director of the AntiVivisection Society and formerly president of the League for the Prohibition of Cruel Sports, on April 10, aged eighty-one years. 